\title{
Comparison of Different Teaching Method in First Year Medical Students: Both Subjectively and Objectively
}

\author{
Dr Madhura V. Motagi ${ }^{1}$, Chethan H.A. ${ }^{1}$ \\ ${ }^{1}$ Professor, Dept of Physiology, Subbaiah Institute of Medical Sciences
}

\begin{abstract}
Aim: Our study was to compare three different teaching method in first year medical students.

Objectives: To assess the outcome and perception of students towards teaching method.

Method: 150 students were divided randomly in to 3 different groups as group A (attended Lecture), group $\mathrm{B}$ (attended demonstration) group $\mathrm{C}$ [attended small group discussion (SGD)], topic was Introduction to BP. As a pretest all the groups had answered a set of structured 25 MCQs, after attending their respective teaching sessions, immediately post test I and after 1 month post-test II was conducted. For subjective assessment likert scale was used.
\end{abstract}

Statistical Analysis: Paired t test was used for comparison. "P" $<0.05$ was considered as statistically significant.

Results: There was a significant difference between pre-test and post-test I, pre-test and post-test II in all the groups $(\mathrm{P}<0.001)$. When we compared post-test I and II, group A and B showed the significant difference $(\mathrm{P}<0.05)$, as their performance in post-test II has reduced, but there was no significant difference showed by group C between post-test I and II, as their performance in post-test II has not reduced. Subjectively also Students preferred SGD as better teaching method.

Concussion: Looking at results, clearly states that the SGD is better compared to other two method, both subjectively and objectively.

Keywords: Lecture class, demonstration, small group discussion, MCQs.

\section{Introduction}

From the beginning didactic lectures are considered as the method of teaching for large group in medical students. It is challenging task to teachers to deliver the vast subject in a short time of lecture class about 40 to 50 minutes, and also to students where there is no interaction

\section{Corresponding Author:}

\section{Dr. Chethan H.A.}

Professor, Dept. of Physiology, Subbaiah Institute of Medical Sciences

e-mail: drhachethan@rediffmail.com

Ph. Number: 9844255627 and it promotes passive learning and fails to motivate the students. Since few decades many innovative modalities of learning are being implemented to make the learning process interesting like tutorials, seminars, case-based discussions, small group discussions ${ }^{1}$. Traditional didactic lecture is more passive and less effective as a teaching tool compared with active learning method like problem-based learning. But, a well-organized lecture can be one of the most effective ways to integrate and present information from multiple sources on difficult topics. So, assistance is needed to enhance the quality of lecture in the form of audio-visual aid like power point teaching which has now become the most popular package of teaching method ${ }^{2}$. Student motivation and performance improve when the instruction is adapted to student learning preferences and styles. According to the 
experience of the various authors, it was very difficult to retain the attention and interest of medical students in subjects, so there was introduction of problem based learning and small group discussion in addition to didactic lectures, and the students met this approach with enthusiasm. From this success, they began to consider ways to incorporate this technique into the traditional didactic lecture activities ${ }^{3}$. The emerging trend all over the world is to have a problem-based, integrated student-centred medical curriculum, demanding active participation from the students and facilitating selfdirected learning ${ }^{4}$. Based on the previous research studies students have preference for chalk and talk ${ }^{5}$, chalk and talk with $\mathrm{PPT}^{6}$, small group discussion ${ }^{1,7}$ and case based discussion ${ }^{3}$. So the aim of our study is to compare three different teaching modalities in first year medical students in Physiology (Lecture class, Demonstration and small group discussion (SGD)).

\section{Material and Method}

Study was conducted in first year medical students of Subbaiah Institute of Medical Sciences, Karnataka, India, after taking informed consent from all the volunteers.

A batch of 150 students were considered for study, in which we have divided them in to 3 groups randomly and equally including both girls and boys. Group A had 23 boys and 27 girls(total 50), group B had 24 boys and 26 girls(total 50), and Group C had 24 boys and 26 girls(total 50). The topic chosen was introduction to BP, with no prier intimation.

Group A attended lecture class, group B attended demonstration and Group $\mathrm{C}$ attended SGD. All the session were conducted by only one faculty and conducted in sequence one after the other(to avoid teacher bias and also time bias).

Objective Assessment: Around 25 MCQ's were prepared related to the topic and all students had answered to those MCQ's before and after their respective sessions. The test before the session was named as pre-test and the test after the session was posttest I and one more post test was conducted after one month that was named as post- test II. Pre-test, post-test I and Post-test II marks were compared in all the groups after respective sessions of teaching.

All the 150 student were asked to come to lecture class at sharp 8 o' clock, then we divided student in 3 groups (as previously mentioned, and students were not aware of which topic is going to be taken and also what kind of teaching method they were involved). Group A stayed in lecture class and other two groups went to their respect practical hall and seminar hall(to avoid topic bias we told one group to read thyroid and other to read cortisol as we will come and discuss).

In Lecture class group A attended pre-test, $20 \mathrm{~min}$ lecture class on Introduction to BP and post-test, so this took around $30 \mathrm{~min}$. Then same faculty took pre-test, practical demonstration of BP for $20 \mathrm{~min}$ and post-test for group B. the last group was $\mathrm{C}$, where pre-test was conducted, then SGD on BP which took more time (as it was discussion, we had to divided 50 students in to 6 small groups, provided them textbooks and manuals to read about introduction to BP for about 30 mins and then we discussed) and post-test was conducted for group C. (session were conducted by same faculty, for conducting pre and post other faculty were involved).

Subject Assessment: To find out the students perception towards the different teaching method, five questionnaires were given to each group as a feedback form, which they filled along with the post tests. To evaluate five point likert scale was used.

Statistical Analysis: Statistical analysis was done using paired "t" test to compare the pre test,post-test I and II of group A, group B and group C . A "p" value of less than 0.05 was considered as statistically significant. 


\section{Results}

Table 1: Paired t test (pre-test and post-test I)

\begin{tabular}{|c|c|c|c|c|c|}
\hline & Magn. & $\mathrm{N}$ & Sid. dexiation. & t) valug & P yalue \\
\hline 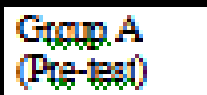 & 8.15 & 47 & 2.797 & \multirow[b]{2}{*}{-23.692} & \multirow[b]{2}{*}{$0.000^{4}$} \\
\hline $\begin{array}{l}\text { Grop.A } \\
\text { (Pod-tert. I) }\end{array}$ & 17.38 & 47 & 2.533 & & \\
\hline 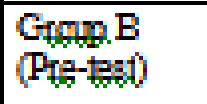 & 7.02 & 44 & 2.565 & \multirow{2}{*}{-17.991} & \multirow[b]{2}{*}{$0.000^{4}$} \\
\hline \begin{tabular}{|l} 
Grops B \\
(Pot-test I)
\end{tabular} & 15.84 & 44 & 2.658 & & \\
\hline 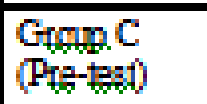 & 6.72 & 46 & 2.697 & \multirow{2}{*}{-15.586} & \multirow[b]{2}{*}{$0.000^{\circ}$} \\
\hline $\begin{array}{l}\text { Grop.C } \\
\text { (Pot-test. I) }\end{array}$ & 15.35 & 46 & 3.695 & & \\
\hline
\end{tabular}

$*=\mathrm{P}$ value $<0.05$

Table 2: Paired t test (pre-test and post-test II)

\begin{tabular}{|c|c|c|c|c|c|}
\hline & Mequp. & $\mathrm{N}$ & Sid deviation. & 1. value & P value \\
\hline $\begin{array}{l}\text { GraupA } \\
\text { (Pe-teatt) }\end{array}$ & 8.02 & 44 & 2816 & \multirow{2}{*}{-13.169} & \multirow[b]{2}{*}{$0.000^{*}$} \\
\hline $\begin{array}{l}\text { GroupA } \\
\text { (Pct-10t II) }\end{array}$ & 14.18 & $\overline{44}$ & 2.912 & & \\
\hline $\begin{array}{l}\text { Group B } \\
\text { (Pe-teat) }\end{array}$ & 6.88 & 41 & 2.472 & \multirow{2}{*}{-14.647} & \multirow[b]{2}{*}{$0.000^{*}$} \\
\hline $\begin{array}{l}\text { GrappB } \\
\text { (Pot-1out I) }\end{array}$ & 14.41 & 41 & 3.331 & & \\
\hline $\begin{array}{l}\text { GroupC } \\
\text { (Pe-tegt) }\end{array}$ & 6.91 & 44 & 2595 & \multirow{2}{*}{-16.885} & \multirow[b]{2}{*}{$0.000^{*}$} \\
\hline $\begin{array}{l}\text { Group C } \\
\text { (Pct-1pat I) }\end{array}$ & 15.27 & 44 & 2.944 & & \\
\hline
\end{tabular}

${ }^{*}=\mathrm{P}$ value $<0.05$ 
Table 3: Paired t test(post-test I and post-test II)

\begin{tabular}{|c|c|c|c|c|c|}
\hline & Mean & $\mathrm{x}$ & sd darason & to whe & P valse \\
\hline $\begin{array}{l}\text { Goop A } \\
\text { (Poitati) } \\
\text { GropA } \\
\text { (PonteiII) }\end{array}$ & $\begin{array}{l}1736 \\
14+15\end{array}$ & $\begin{array}{l}44 \\
44\end{array}$ & $\begin{array}{l}295 \\
2912\end{array}$ & 7.579 & $0000 \%$ \\
\hline $\begin{array}{l}\text { Grop B } \\
\text { (Pouteit) } \\
\text { Grop B } \\
\text { (Pot-tetII) }\end{array}$ & $\begin{array}{l}1576 \\
14+41\end{array}$ & 41 & $\begin{array}{l}265 \\
3331\end{array}$ & 2165 & $0.036^{*}$ \\
\hline 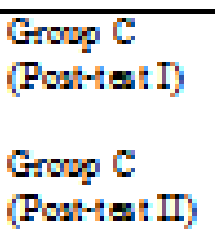 & 1517 & 44 & 2944 & $2 n$ & 0753 \\
\hline
\end{tabular}

Table 4: Livert scale (Subjective assesment)

\begin{tabular}{|c|c|c|c|c|c|}
\hline $\begin{array}{l}\text { Lecture dass } \\
\text { (47 students) }\end{array}$ & $\begin{array}{l}\text { Strongly } \\
\text { agre }\end{array}$ & $\begin{array}{l}\text { Demoustration } \\
\text { (45 students) }\end{array}$ & $\begin{array}{l}\text { Stongy } \\
\text { agrea }\end{array}$ & $\begin{array}{l}\text { Group discussion } \\
\text { (45students) }\end{array}$ & $\begin{array}{l}\text { Strongly } \\
\text { agree }\end{array}$ \\
\hline $\begin{array}{l}\text { Visualizing } \\
\text { concepts }\end{array}$ & $18(38 \%$ & $\begin{array}{l}\text { Visualizing } \\
\text { concepts }\end{array}$ & 36,8009 & $\begin{array}{l}\text { Visualizing } \\
\text { concepts }\end{array}$ & $19(42 \%$ \\
\hline $\begin{array}{l}\text { Suataining } \\
\text { interest }\end{array}$ & $22(46 \%)$ & $\begin{array}{l}\text { Subtaining } \\
\text { interest }\end{array}$ & $26(57 \%)$ & Sustaining interest & $28(620 \%$ \\
\hline $\begin{array}{l}\text { Remenbering } \\
\text { facts }\end{array}$ & $20,42 \%$ & $\begin{array}{l}\text { Remenbering } \\
\text { facts }\end{array}$ & $19(42 \%)$ & $\begin{array}{l}\text { Renembering } \\
\text { facts }\end{array}$ & $27(60 \%)$ \\
\hline $\begin{array}{l}\text { Understanding } \\
\text { better }\end{array}$ & $22(46 \%$ & $\begin{array}{l}\text { Understanding } \\
\text { better }\end{array}$ & $28(55 \%)$ & $\begin{array}{l}\text { Understanding } \\
\text { better }\end{array}$ & $33(730 \%$ \\
\hline $\begin{array}{l}\text { Applying } \\
\text { lnowledge }\end{array}$ & $17(36 \%$ & $\begin{array}{l}\text { Applying } \\
\text { hnowledge }\end{array}$ & $22(48 \%)$ & $\begin{array}{l}\text { Applying } \\
\text { knowldge }\end{array}$ & $25(509)$ \\
\hline
\end{tabular}




\section{Discussion}

Looking at our results all the groups have performed significantly better in post-test I compared to pretest $(\mathrm{P}=0.00)$ (Table 1$)$ and also significant $(\mathrm{P}=0.00)$ difference is there between pre-test and post-test II in all the groups (Table 2). But looking at the Table 3 where we have compared between post-test I and post-test II in which students performance has reduced significantly $(\mathrm{P}<0.05)$ in post-test II in group $\mathrm{A}$ (who attended lecture) and group B (who attended demonstration) but post-test II performance is not reduced in group C (who attended discussion), this shows that small group discussion (SGD) is better way of teaching in which students can still remember the subject even after 1 month and performed well compared to other two teaching method. Our results were similar to the other studies ${ }^{1,7}$. In subjective assessment of our study, student strongly agreed that group discussion is much better than lecture class and demonstration type of teaching (table 4). So both objective and subjective assessments of our study showed group discussion is better way of teaching. There are studies who showed that small group discussion is better way of teaching in other subjects like in biochemistry ${ }^{8}$ and in microbiology ${ }^{9}$. The study carried out by ${ }^{10}$, where instead of using MCQs they used short answer questions (SAQs) and assessed their retention after 15 days of small group discussion, they found it as very effective way of method of teaching. Small group discussion was advantageous because it motivates students to involve in discussion actively and helps for retention and also students were able to express their ideas and then receive input from the group members 1 ,

9. Small group discussion favours participation of everyone, as students are more comfortable in small groups. They are made to prepare specific tasks for the group to answer to the solution. All students when they work in groups, it enhances their reasoning abilities as well ${ }^{11}$. Some studies have even proved that integrated teaching is be more effective in improving the knowledge and attitude of students than traditional lecturing method, so integrated method of teaching needs to be implemented in the medical education curriculum for better understanding and best outcome ${ }^{12}$. In our study we used demonstration as one more method of teaching, where students post-test II performance was reduced, may be OSPE as assessment is better method of assessing with regards to practical demonstration of teaching BP, but to avoid the bias of assessment we used same MCQs method in our study.
Teaching in Physiology is followed always through lectures, practical's and tutorials. According to the university curriculum physiology is taught with the help of lecture classes, as delivering of more information to large group of students, but it is passive method and also teachers centred as a teacher it is not only duty to deliver large information to students but make sure that students should understand the information and can use that skilfully once they enters the clinical departments. Now a days there are so many types of teaching method including integrated teaching which actually help students to correlate the subjects and help them once they enter the final year.

Limitations: To avoid the other biases like, students should not know in which type of teaching they are going to attend, we didn't give any prier intimation to the group which came for discussion, as they need more time to read, we gave them little less time once the session started. For demonstration method of teaching we would have used OSPE, but we didn't used because assessment bias would have arrived.

\section{Conclusion}

Our study indicates that small group discussion is better than the lecture class and demonstration type of teaching both subjectively and objectively. To teach Physiology small group discussion is better method, as most of the topics can be discussed but not all can be demonstrated and also retention is much better after small group discussion compared to other two method in our study.

\section{Conflict of Interest: Nil}

\section{Source of Funding: Self}

Ethical Clearance: Got from institutional ethical committee.

\section{References}

1. Suhasini. P, Joshi, KP, Yamini D, Swaroopa Chary RS, Sarma D.V.H.S. Educational outcomes of small group discussion versus traditional lecture among first year undergraduate medical students.Journal of Education Technology in Health Sciences 2017;4(3):93-96.

2. Joshi KP, Robins M, Yanadi Reddy M. Perception and preferences of teaching and learning method in community medicine: a cross sectional study 
Int J Community Med Public Health. 2018 Jul;5(7):2821-2824.

3. Madhura M, Kannan N, Santosh P. Evaluation of different teachibg modalities for better understanding of subject in first year medical students. International Journal of Biomedical Research 2015; Vol 6(5)

4. Vimal MH, Namrata AT, Purushottam AG Student's preferences for learning in medical education Int J Community Med Public Health. 2015 Aug; 2(3):328-330

5. Vikas S, Prerna U, Mushtaq A, Virendra K. An assessment of teachers' preference for lecture delivery method in medical education Educational Research and Review 2010 Vol. 5 (9), pp. 533-537.

6. Rajani SN, Yogananda R, Rajesh P.Effective physiology teaching method: from the perspective of first year MBBS students Indian J Clin Anat Physiol. 2016; 3(3): 336-338.

7. Joshi KP, Suhasini P, Robins M. Assessment of educational outcomes of small group discussion versus traditional lecture format among undergraduate medical students Int J Community Med Public Health. 2018 Jul; 5(7):2766-2769
8. Chetana. PH. Effectiveness of Small Group Discussion Sessions in Teaching Biochemistry for Undergraduate Medical Students South East Asian Journal of Medical Education 2014; Vol 8(1):77-81

9. Sudheendra $\mathrm{K}$, Chandrakanth $\mathrm{C}$ Evaluation of Small Group Discussion as a Teaching Method in Microbiology for Second Year medical Students in Brims Bidar: A Pilot Study Int.J.Curr.Microbiol. App.Sci 2015; 4(9): 1001-1003

10. Zachariah B, Bidhan KC, Sridhar MG, Nandeesha H, Renuka P, Sajita S, et al Formulation of Questions Followed by Small Group Discussion as a Revision Exercise at the End of a Teaching Module in Biochemistry Biochemistry and molecular biology education 2007; Vol 35(1):45-48

11. Vijaya SD. Effect of integrated teaching versus conventional lecturing on MBBS phase I Students. Recent Research in Sciences and Technology. 2010;2(11):40-48

12. Basanta KB, Narahari A, Kamalakanta S. Evaluation of impact of an integrated lecture method of teaching among undergraduate medical students, compared to traditional didactical lectures in reference to antenatal care Int J Adv Med. 2017; 4(3):640-644 